\begin{tabular}{|l|l|l||}
\hline \multicolumn{2}{|c|}{ PublisherInfo } \\
\hline \hline PublisherName & $:$ & BioMed Central \\
\hline \hline PublisherLocation & $:$ & London \\
\hline \hline PublisherImprintName & $:$ & BioMed Central \\
\hline \hline
\end{tabular}

\title{
Death by endonuclease
}

\begin{tabular}{|l|l|l||}
\hline \multicolumn{2}{|c|}{ ArticleInfo } \\
\hline \hline ArticleID & $:$ & 4143 \\
\hline \hline ArticleDOI & $:$ & $10.1186 /$ gb-spotlight-20010710-03 \\
\hline \hline ArticleCitationID & $:$ & spotlight-20010710-03 \\
\hline \hline ArticleSequenceNumber & $:$ & 214 \\
\hline \hline ArticleCategory & $:$ & Research news \\
\hline \hline ArticleFirstPage & $:$ & 1 \\
\hline \hline ArticleLastPage & $:$ & 2 \\
\hline \hline & & RegistrationDate : 2001-07-10 \\
ArticleHistory & $:$ & OnlineDate $\quad$ 2001-07-10 \\
\hline \hline ArticleCopyright & $:$ & BioMed Central Ltd2001 \\
\hline \hline ArticleGrants & $:$ & \\
\hline \hline ArticleContext & $:$ & 130592211 \\
\hline \hline
\end{tabular}




\section{Jonathan B Weitzman}

Email: jonathanweitzman@hotmail.com

The apoptotic suicide programme involves fragmentation of nucleosomal DNA. In the July 5 Nature, two groups report identification of a mitochondrial nuclease that induces DNA degradation associated with apoptosis in both worms and mammals. Parrish et al. performed a genetic screen in Caenorhabditis elegans to search for suppressors of an activated cell-death protease (CED-3) mutant (Nature 2001, 412:90-94). After screening 3,000 mutagenized haploid genomes, they identified an apoptosis-related gene that they named cps-6 (CED-3 protease suppressor). Analysis of the cps- 6 mutation and RNAi gene inactivation experiments revealed delayed appearance of cell corpses during nematode development. The cps-6 gene is homologous to the mammalian mitochondrial endonuclease G. In an accompanying paper, $\mathrm{Li}$ et al. show that the role of endonuclease $\mathrm{G}$ in apoptosis is conserved in human cells (Nature 2001, 412:95-99). They used a reconstituted in vitro system to demonstrate the release of a DNase from mitochondria during apoptosis. They performed biochemical purification from mouse liver mitochondria to isolate the endoG enzyme. The purified enzyme was sufficient to generate the nucleosomal DNA fragmentation characteristic of dying cells. EndoG is released from the mitochondria upon apoptotic stimulation, translocates to the nucleus and cleaves DNA in a caspase-dependent manner. These results provide convincing evidence linking DNA degradation to cell-death execution and stress the importance of mitochondria in the apoptotic programme.

\section{References}

1. Apoptotic DNA fragmentation

2. Nature, [http://www.nature.com]

This PDF file was created after publication. 